\title{
Complete Remission of Acute Myeloid Leukemia in Induction and Consolidation Chemotherapy without Bone Marrow Transplantation: Lessons Learned from Good Presentation Case
}

\author{
Tuti Sri Hastuti, ${ }^{1,2}$ Rachmat Sumantri, ${ }^{2}$ Indra Wijaya ${ }^{2}$ \\ ${ }^{1}$ Department of Internal Medicine, General Hospital of Cianjur, Indonesia, \\ ${ }^{2}$ Division of Medical Hematology-Oncology, Department of Internal Medicine \\ Faculty of Medicine Universitas Padjadjaran/Dr. Hasan Sadikin General Hospital Bandung, Indonesia
}

\begin{abstract}
Acute myeloid leukemia (AML) is a clinically morphologically and genetically heterogeneous disease with variable responses to therapy. The majority of the patients eventually relapse and succumb to the disease. Therapeutic modalities of induction chemotherapy, consolidation, and bone marrow transplantation are intended to achieve complete remission. Induction therapy with cytarabine and anthracycline remains the standard of care in AML. Consolidation treatment is necessary to prevent recurrence, which may reach $90 \%$ without this treatment. Options for consolidation therapy are conventional chemotherapy and bone marrow transplantation. Bone marrow transplantation represents the only realistic chance of long-term remission in patients with a high cytogenetic risk. The risk of recurrence of AML is determined mainly by the patient's age and genetic factors. In younger patients, complete remission (CR) rates of $\geq 80 \%$ may be achieved, with 5 -year overall survival (OS) of 40\%. In Dr. Hasan Sadikin General Hospital Bandung during the period of 2013-2018, 12 cases of LMA underwent chemotherapy. This case study discusses a young patient with AML who has successfully reached complete remission using induction and consolidation chemotherapy without bone marrow transplantation.
\end{abstract}

Key words: Acute myeloid leukemia, chemotherapy, complete remission

\section{Remisi Lengkap Pasca Kemoterapi Induksi dan Konsolidasi tanpa Transplantasi Sumsum Tulang pada Leukemia Mieloblastik Akut: berdasar atas Contoh Kasus}

\begin{abstract}
Abstrak
Leukemia mieloblastik akut adalah sekelompok penyakit yang memiliki gejala klinis, morfologi sel darah, kelainan genetik, dan respons terhadap terapi yang sangat bervariasi. Sebagian besar pasien leukemia mieloblastik akut (LMA) biasanya akan mengalami kekambuhan dalam perjalanan penyakitnya. Kejadian kekambuhan dalam 5 tahun sebesar 9\% untuk kekambuhan di ekstramedulari dan 29\% kekambuhan di sumsum tulang. Tujuan terapi pada LMA adalah mencapai remisi lengkap dan mencegah kekambuhan melalui modalitas kemoterapi dan transplantasi sumsum tulang. Transplantasi sumsum tulang diindikasikan pada pasien LMA dengan risiko sitogenetik yang tinggi. Tingkat remisi lengkap $\geq 80 \%$ dapat dicapai, terutama pada pasien yang lebih muda dengan kelangsungan hidup keseluruhan 5 tahun 40\%. Di Rumah Sakit Dr. Hasan Sadikin Bandung, selama kurun waktu 2013-2018 didapatkan 12 kasus LMA yang menjalani kemoterapi. Pada artikel ini didiskusikan 1 pasien LMA usia muda yang berhasil mencapai remisi lengkap dengan kemoterapi induksi dan konsolidasi tanpa menjalani transplantasi sumsum tulang dengan terapi pendukung yang optimal selama pemberian kemoterapi.
\end{abstract}

Kata kunci: Kemoterapi, leukemia mieloblastik akut, remisi lengkap

Corresponding Author: Tuti Sri Hastuti, Department of Internal Medicine, General Hospital of Cianjur, Jalan Rumah Sakit No 1 Cianjur 43216, West Java, Indonesia, Email: tutisrihastuti@ymail.com 


\section{Introduction}

Acute myeloblastic leukemia (AML) is a disease with heterogeneous clinical features as well as blood cell morphology and genetic abnormalities with various responses to therapy. Most AML patients, in the course of their disease, will usually experience recurrence and will eventually die unless they undergo bone marrow transplantation which will lead to a better prognosis. ${ }^{1}$ Therapies for AML patients include induction chemotherapy, consolidation, and bone marrow transplantation which are aimed at to achieve complete remission (CR) for a longest period possible without recurrence. ${ }^{2}$

At the time of AML diagnosis, induction chemotherapy is given with the aim of rapidly improving bone marrow function to normal. ${ }^{3}$ Induction chemotherapy with cytarabine and anthracycline is the standard treatment in AML. The standard therapy combination is a 7 plus 3 regimens, namely infusion of cytarabine for 7 days in a row with a dose of 100 or $200 \mathrm{mg} / \mathrm{m}^{2}$ per day on day 1 to day 7 and daunorubicin with a dose of $60 \mathrm{mg} / \mathrm{m}^{2}$ per day on day 1 to $3 .^{4}$

Cytarabine (ara-C) has become an important component of combination chemotherapy for induction and consolidation of AML. The administration of high-dose cytarabine results in long-term survival in AML and causes a higher incidence of complete remission. Analysis of the effect of dose and dose intensity on the duration of AML remission shows that the induction dose of cytarabine and daunorubicin significantly affects the duration of remission. ${ }^{4}$

The prognosis of AML patients is strongly influenced by the AML subtype, chromosomal abnormalities (cytogenetic), age, white blood cell count, previous AML-causing haematological disorders, AML caused byother previous cancer therapies, infection, and AML status after therapy is given., ${ }^{5,6}$ In younger patients, complete remission rate of $\geq 80 \%$ can be achieved, with an overall 5 years survival (OS) of $40 \%{ }^{4}$

Every AML patient who is undergoing chemotherapy must receive good supportive therapies to deal with the most likely side effects such assevere neutropenia to febrile neutropenia, severe thrombocytopenia, anemia, diarrhea, nausea, and vomiting. ${ }^{3}$ The given therapy regimen and therapeutic response may differ between younger and older patients of AML. There are no definite definition on the the age limits of younger and older patients in AML although several studies have defined elderly AML patients as patients whose age is above 55-
60 years. $^{3}$ AML patients who undergo intensive induction therapy do not always achieve a complete response with 10-40\% AML patients who undergo induction chemotherapy do not reach complete response and are included in the primary refractory or resistant group. These patients should be treated with allogeneic hematopoietic stem cell transplantation (HSCT) therapy if they meet the criteria. ${ }^{7}$

\section{Methods}

This was a descriptive study on AML patients treated in Dr. Hasan Sadikin General Hospital Bandung. Data were obtained from adult AML patients who underwent chemotherapy from 2013-2018, comprising of 12 patients. The average age of patients wass 31 years $(20-39$ years) with more females $(n=8)$ than males $(n=4)$. From these patients, data regarding AML therapy and response to therapy were collected.

To get an in-depth understanding on AML, AML therapy, and response to therapy, one particular case was described in details in this study.

\section{Results}

From the 12 patients included in this study, it was revealed that most patients received cytarabine and daunorubicin chemotherapy, On analysis, it was found that the therapeutic responses of the 12 patients who underwent chemotherapy varied with 1 patients showed a complete response, 7 presented partial responses, and 4 did not show any response to therapy. Ten patients then died because of the disease and 2 patients survived. Of those who survived, 1 patient did not respond to chemotherapy and then underwent supportive therapy, while 1 patient achieved a complete response after induction chemotherapy and survived to date, i.e. approximately 3 years after induction chemotherapy. None of the patients underwent HSCT due to financial reasons. Details on types of chemotherapy, response to therapy, and patient's status are listed in Table 1.

One female patient was selected for detailed description of AML, AML therapy, and response to therapy. This 18-years-old patient was diagnosed with AML and undergwent induction and consolidation chemotherapy with cytarabine and daunorubicin, then underwent complete remission for 3 years until now without undergoing a bone marrow transplant. 
Tuti S. Hastuti, et al.: Complete Remission of Acute Myeloid Leukemia in Induction and Consolidation Chemotherapy without Bone Marrow Transplantation

Table 1 Adult Patients of Acute Myeloblastic Leukemie who Underwent Chemotherapy Between 2013-2018 in Dr. Hasan Sadikin Hospital, Bandung

\begin{tabular}{|c|c|c|c|c|}
\hline Sex & Age & Chemotherapy & Response of Therapy & Status \\
\hline $\mathrm{F}$ & 23 & 5-3 regimen & Did not respond & Lived-supportive \\
\hline $\mathrm{F}$ & 30 & $7-3$ regimen & Partial response & Died \\
\hline $\mathrm{F}$ & 20 & $7-3$ regimen & Partial response & Died \\
\hline $\mathrm{F}$ & 37 & 5-3 regimen & Did not respond & Died \\
\hline $\mathrm{F}$ & 38 & 5-3 regimen & Partial response & Died \\
\hline $\mathrm{F}$ & 34 & $5-3$ regimen & Partial response & Died \\
\hline $\mathrm{F}$ & 39 & $5-3$ regimen & Partial response & Died \\
\hline M & 28 & $5-3$ regimen & Did not respond & Died \\
\hline M & 31 & $5-3$ regimen & Partial response & Died \\
\hline M & 37 & Cy-Dauno-Vin & Did not respond & Died \\
\hline $\mathrm{F}$ & 20 & 5-3 regimen & Complete response & Survived without relapse \\
\hline M & 36 & 5-3 regimen & Partial response & Died \\
\hline
\end{tabular}

On closer examination, there are several factors that are expected to influence the patient's good prognosis and outcome.

The young patient, who was a student, was admitted to the hospital after having a continuous fever for 2 weeks. She also experienced bleeding swollen gum. No joint ache was felt. From the physical examination, it was revealed that the patient was febrile with other vital signs were within normal limits. Anemic conjunctiva, non-icteric sclera, gum hypertrophy, and enlarged lymph nodes measuring less than 2 $\mathrm{cm}$ in both sides of the neck. Hepatomegaly with splenomegaly was not palpable but the traube space was filled.

The result of routine blood laboratory testing presented a Hemoglobin (Hb) level of $9.6 \mathrm{~g} /$ $\mathrm{dL}$, leukocytes of $23 \times 10^{9} / \mathrm{mm}^{3}$ and platelet (Tr) of $70 \times 10^{9} / \mathrm{mm}^{3}$. Bone marrow aspiration was then performed with the following myelogram results : blast (several blasts with curved nuclei, vacuolized cytoplasm) $91 \%$, promielocytes $0 \%$, myelocytes $0.5 \%$, metamielocytes $0 \%$, rods $0 \%$, segment $1 \%$, eosinophils $0 \%$, basophils $0 \%$, monocytes $3.5 \%$, lymphocytes $1 \%$, plasma cells $1 \%$, pronormoblast $0 \%$, normoblast basophils $0 \%$, polycromatophil normoblast $1 \%$, acidophilic normoblast $1 \%$. Meanwhile, the bone marrow morphology presented the following results: increased cellularity; erythropoetic series decreases; granulopoietic series ratio of $\mathrm{M}: \mathrm{E}=$ 46:1; megakaryocyte thrombopoietic series is
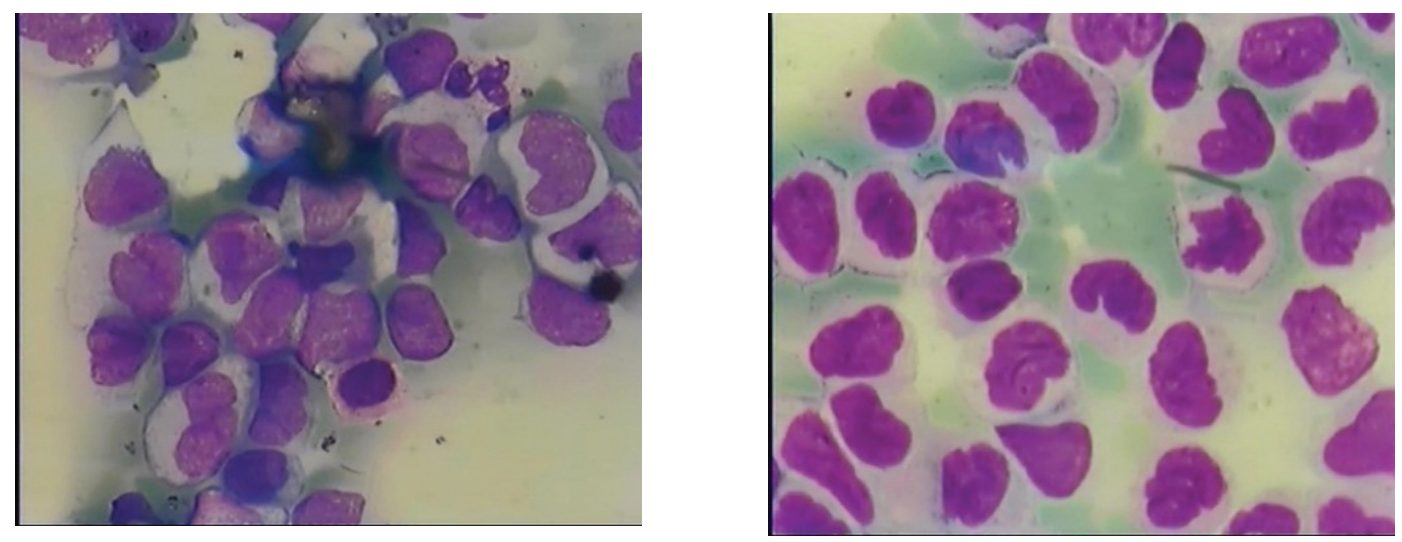

Figure 1 Bone Marrow Smear of the Patient Appears Dominated by the Monoblast Cells 

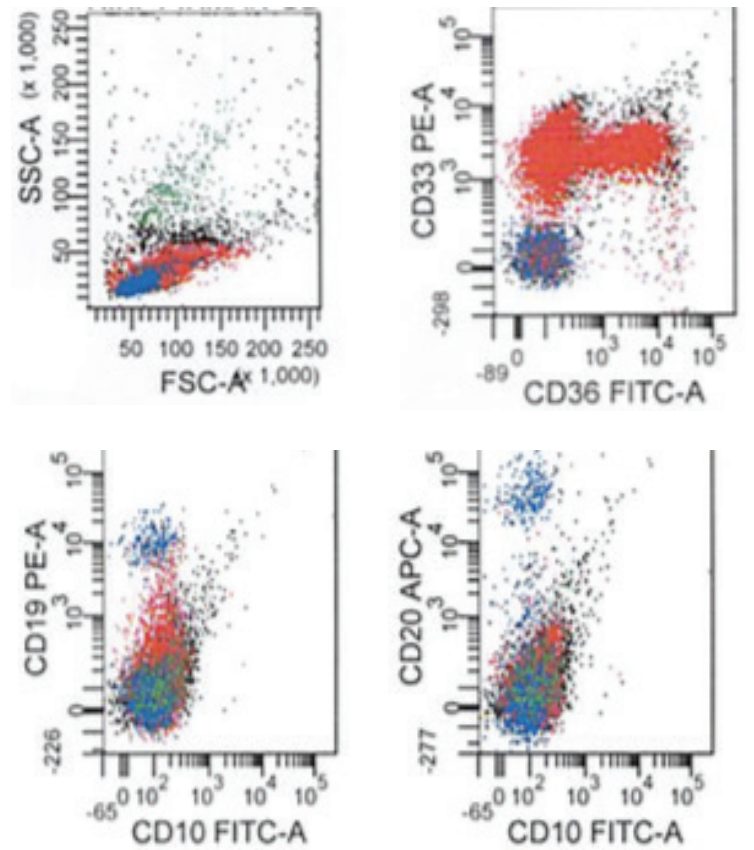
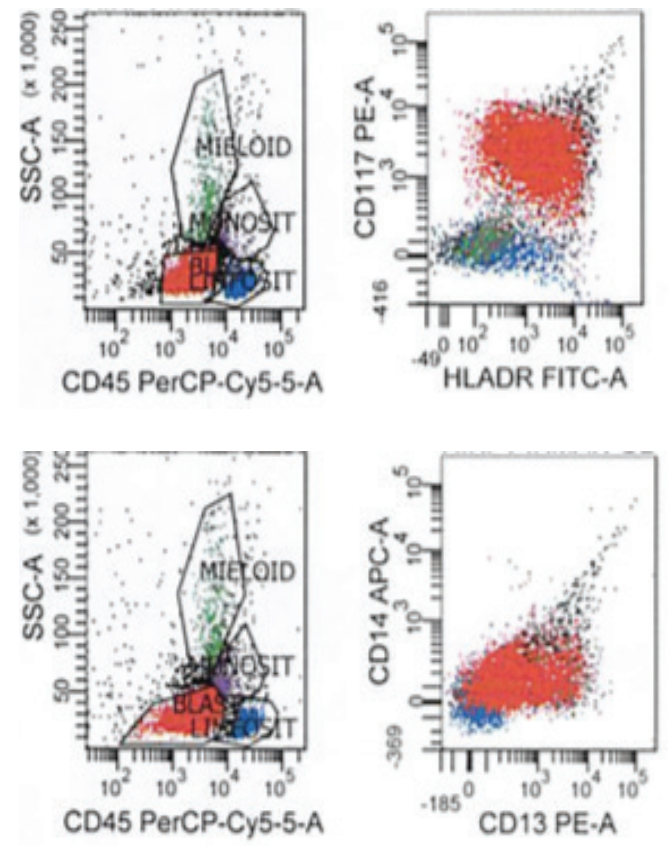

Figure 2 Immunophenotyping of Leukemia of the Patient. Markers for LMA were Obtained in CD33, CD36, HLA-DR and CD 13; and Negative for CD19, CD10, and CD20

rare, platelet formation is lacking. It was then concluded that there was an increase in blast cellularity of $91 \%$ anderythrocyte and platelet series suppression, leading to the conclusion of acute myeloid lekemia (AML M5a).(Figure 1)

Based on these findings, the patient was then diagnosed as suffering from acute myeloid leukemia subtype M5a and it was decided that this patient should receive induction chemotherapy with cytarabine $2 \times 100 \mathrm{mg}$ iv, day 1 to 5 and daunorubicin $60 \mathrm{mg}$ i.v., day 1 to 3 . While undergoing induction chemotherapy, the patient experienced severe pancytopenia with febrile neutropenia with the lowest leukocyte count of $0.6 \times 10^{9} / \mathrm{mm}^{3}$ on day 14 after chemotherapy and the lowest absolute neutrophil count of 12/ $\mathrm{mm}^{3}$. Nono blast was found in peripheral blood. Patients underwent treatment for 1 month. After the laboratory parameters were improved, she then received consolidated chemotherapy with cytarabine $2 \times 100 \mathrm{mg}$ iv, day 1 to 5 and daunorubicin $60 \mathrm{mg}$ i.v., day 1 to 2 . During this consolidation chemotherapy, patients also experienced severe neutropenia. The treatment lasted for approximately 3 weeks.

One month after the consolidation chemotherapy, a complete hematological laboratory examination was done with the following results: $\mathrm{Hb}$ level of $10 \mathrm{~g} / \mathrm{dL}$, leukocytes of $4.2 \times 10^{9} / \mathrm{mm}^{3}$, and platelets of $350 \times 10^{9} / \mathrm{mm}^{3}$.
The diff count results were basophil leukocytes 0 , eosinophil 0 , stem 0 , segment 60 , lymphocytes 24 , and monocytes 16. No blast was found. Repeated immunophenotyping of leukemia was then performed on the patient and it was discovered that the gating marker in the blast area did not appear to be a positive dominant marker, showing that there was no dominant positive blast marker. Patient was declared to have complete remission. After 3 years of induction and consolidation chemotherapy, the patient still survives with complete remission condition reflected from the results of the latest routine hematological examinations that show that all values are within normal limits. No examination of bone marrow aspiration after the completion of chemotherapy was done to this patient.

\section{Discussion}

The diagnosis of AML can be established based on morphology, phenotyping, and cytogenetics. ${ }^{6}$ From the morphological features, immature leukocytes (blast) of $>20 \%$ are usually found in peripheral blood or in the bone marrow, unless the AML was gained cytogenetically with $t(15$; 17), $t(8 ; 21)$, inv (16) or $t(16 ; 16)$, whichdoes not require $>20 \%$ of blast. Fromimmunophenotyping 
Tuti S. Hastuti, et al.: Complete Remission of Acute Myeloid Leukemia in Induction and Consolidation Chemotherapy without Bone Marrow Transplantation

Table 2 Risk Stratification Based Cytogenetic Abnormalities According to ELN 2017*

\begin{tabular}{|c|c|}
\hline Category of Risks & Genetic Abnormalities \\
\hline \multirow[t]{2}{*}{ Favorable (good) } & $\mathrm{t}(8 ; 21)(\mathrm{q} 22 ; \mathrm{q} 22.1) ; R U N X 1-R U N X 1 T 1 ; \operatorname{inv}(16)(\mathrm{p} 13.1 \mathrm{q} 22)$ or $\mathrm{t}(16 ; 16)$ \\
\hline & $\begin{array}{l}\text { (p13.1;q22); CBFB-MYH11 Mutation of NPM1 or FLT3-ITD or with FLT3- } \\
\text { ITD }^{\text {low }} \text { Mutation of biallel CEBPA }\end{array}$ \\
\hline \multirow{3}{*}{ Intermediate } & $\begin{array}{l}\text { Mutation of NPM1 and FLT3-ITD } \\
\text { high } \\
\text { ITD or with FLT3-ITD }^{\text {low }} \text { (without poor risk of genetic lesion) } \mathrm{t}(9 ; 11)\end{array}$ \\
\hline & (p21.3;q23.3); MLLT3-KMT2A. Cytogenetic abnormalities which are not \\
\hline & included to the good or poor risks. \\
\hline \multirow{3}{*}{ Adverse / Poor } & $\begin{array}{l}\mathrm{t}(6 ; 9)(\mathrm{p} 23 ; \mathrm{q} 34.1) ; D E K-N U P 214 \mathrm{t}(\mathrm{v} ; 11 \mathrm{q} 23.3) ; \text { KMT2A rearranged; } \\
\mathrm{t}(9 ; 22)(\mathrm{q} 34.1 ; \mathrm{q} 11.2) ; B C R-A B L 1 \operatorname{inv}(3)(\mathrm{q} 21.3 \mathrm{q} 26.2) \text { or } \mathrm{t}(3 ; 3)\end{array}$ \\
\hline & $(\mathrm{q} 21.3 ; \mathrm{q} 26.2) ; \operatorname{GATA2,MECOM}(E V I 1)-5$ or $\operatorname{del}(5 \mathrm{q}) ;-7 ;-17 / \mathrm{abn}(17 \mathrm{p}) 3$ or \\
\hline & $\begin{array}{l}\text { more of chromosome disorder, monosomal cariotype; Wild type NPM1 } \\
\text { and FLT3-ITD }{ }^{\text {Mutation of RUNX1; Mutation of ASXL1; Mutation of }} \\
\text { TP53 }\end{array}$ \\
\hline
\end{tabular}

* NCCH and Döhner H, et al.

Table 3 Risk Stratification and Indication for Bone Marrow Transplantation in AML Patients*

\begin{tabular}{|c|c|}
\hline $\begin{array}{c}\text { Risk Stratification for Recurrence based on } \\
\text { Cytogenetics }\end{array}$ & $\begin{array}{c}\text { Indication for Bone Marrow Transplantation in } \\
\text { First Complete Remission }\end{array}$ \\
\hline $\begin{array}{l}\text { Low risk for recurrence }(35-40 \%) \text { : } \\
t(8 ; 21) \text { with leukocite of }<20 \times 10^{9} / \mathrm{mm}^{3} \\
\text { Inv(16)/t(16;16) } \\
\text { Gen mutation of NPM1 without gen duplication of } \\
\text { FLT3 } \\
\text { Complete remission after molecular first induction }\end{array}$ & $\begin{array}{l}\text { LOW (transplantation is only done when there is } \\
\text { no comorbid factors) }\end{array}$ \\
\hline $\begin{array}{l}\text { Moderate recurrence risk }(50-55 \%) \text { : } \\
\mathrm{t}(8 ; 21) \text { with leukocye of }>20 \times 10^{9} / \mathrm{mm}^{3} \\
\text { Normal cytogenetic (including loss of X or Y } \\
\text { chromosome) } \\
\text { Leukocyte of }<100 \times 10^{9} / \mathrm{mm}^{3} \text { with complete } \\
\text { remission after first induction chemotherapy }\end{array}$ & $\begin{array}{l}\text { MODERATE (transplantation is only done when } \\
\text { there is a few comorbid factors) }\end{array}$ \\
\hline $\begin{array}{l}\text { High risk for recurrence }(70-80 \%) \text { : } \\
\text { One of the criterias of either good or moderate risk } \\
\text { cytogenetically but do not achieve complete } \\
\text { remission after first induction chemotherapy } \\
\text { Normal cytogenetic but leukocyte of }>100 \times 10^{9} / \mathrm{mm}^{3} \\
\text { Every other cytogenetic aberrant }\end{array}$ & $\begin{array}{l}\text { HIGH (transplantation is considered although } \\
\text { there are comorbid factors) }\end{array}$ \\
\hline $\begin{array}{l}\text { Very high risk for recurrence }(>90 \%) \text { : } \\
\text { Monosomal cariotype } \\
\text { Overexpression of Evi-1 gen }\end{array}$ & $\begin{array}{l}\text { VERY HIGH (transplantation is considered } \\
\text { although there are comorbid factors) }\end{array}$ \\
\hline
\end{tabular}

*Muller LP, et al. 
examination of leukemia, Specific markers are obtained from immunophenotyping of leukemia to confirm AML diagnosis. These markers include CD34, CD117, CD33, CD13, HLA-DR; CD65 granulocytic marker, cytoplasmic MPO; monocytic markers of CD14, CD36, CD64; CD41 (glycoprotein IIb/IIIa) megacariositic marker, CD61 (glycoprotein IIIa); and erythroid markers of CD23 5a (glycoporin A), CD36. ${ }^{8}$ In this patient, the diagnosis of AML M5a was established based on bone marrow morphology and myelogram where monoblast morphology showed $91 \%$ of blast. The immunophenotyping for leukemia performed on this patient also showed that it was positive for AML, CD33, CD36, CD13 and HLA-DR.

There are several prognostic factors that can estimate event-free survival (EFS) and overall survival (OS) based on recent studies. The prognosis of patients with AML is affected by cytogenetic abnormalities $(2 / 3)$ and by demographics, clinical symptoms and therapy given $(1 / 3)$. Age is a factor that is independently related to the final outcome of AML patients with increasing age is related to poorer prognosis of AML patients. Patients' general condition and specific comorbidities will also affect the age factor and are associated with the effects of chemotherapy given. ${ }^{8}$ In this case, the patient was 18 years old, with good general condition (WHO performance status with a scale of 1 ) and without other comorbid factors and previous blood disorders such as MDS, MPN or CMML. This patient also never reveived any previous therapy for other cancers before. All of these factors are good prognostic factors that may predict a complete remission in this patient.

The main goal of therapy in new AML cases is the induction of remission, which is done through intensive induction chemotherapy. After achieving remission induction, consolidation therapy is needed to prevent recurrence, which often occurs in AML patient with an incidence of up to $90 \%$. The choice of consolidation therapy is highly dependent on the patient's condition, which can be chemotherapy and/or bone marrow transplantation. The risk of recurrence in AML patients is mainly influenced by patient's age and genetic factors. ${ }^{6}$ The proportion of AML patients with standard induction chemotherapy treatment who achieve complete remission is $20-90 \%$ with $10-95 \%$ will experience a relapse that will generally end with death. ${ }^{5}$

The standard therapy regimen for AML is intensive induction chemotherapy, consolidated chemotherapy, and, when needed and as indicated, bone marrow transplantation. The aim of all these therapies is to achieve complete remission with possible treatment modalities. The combination of chemotherapy in AML is very aggressive and is associated with severe side effects with clinical symptoms that vary greatly from mild to severe and the management of these requires great financial power. ${ }^{2}$ The indications for bone marrow transplantation are determined by cytogenetic features of the patient, where cytogenetic abnormalities in patients are associated with the risk of recurrence. The higher the risk, the higher the indication for bone marrow transplantation is with consideration of the presence of comorbidities. Several studies have shown that bone marrow transplantation is one of the best ways to maintain long-term remission in AML patients who have a high cytogenetic risk. $^{6}$

Every AML patient who will undergo therapy should be examined for cytogenetics to determine the risk stratification that will affect the therapeutic response and the choice of consolidation therapy that the patient will undergo. Based on the cytogenetic and molecular abnormalities, AML patients are divided into 3 groups, namely good (favorable), intermediate or poor risks. (Table 2).

Although the patient in the case did not undergo cytogenetic testing, it is assumed that this patient had a favorable/good risk for cytogenetic features, given the good results achieved. After the diagnosis of AML was established, patient received induction chemotherapy, followed by consolidated chemotherapy using cytarabine and daunorubicin with the protocol of 5 plus 2 . The most common side effect of daunorubicin and cytarabine combination chemotherapy is the occurrence of very severe neutropenia. This also happened to this patient where the lowest neutrophils were up to $12 / \mathrm{mm}^{3}$ on day 14 after chemotherapy.

In view of these these genetic risks, risk stratification for possible recurrence and indications of allogenic bone marrow transplantation is established.

In AML patients who received induction chemotherapy and intensive standard consolidation the proportion of complete remission is $60-80 \%$ at young age and $40-$ $60 \%$ at older age ( $\geq 60$ years). ${ }^{3}$ In this case, the patient was 18 years old and had a good and noncomorbid performance status so that the results achieved were good. Selected consolidated therapy for this patient was consolidated chemotherapy, and not allogenic bone marrow 
transplant, because it is too expensive to do transplant and the patient was not tested for cytogenetically, making it impossible to assess whether the patient met the criteria of high risk for allogenic bone marrow transplants or not.

Therapy evaluation and prognosis assessment in AML patients under therapy can be performed by evaluating whether the patient met the criteria of complete remission (CR), partial remission (CRp), CR with incomplete hematological repair, or morphologic leukemiafree state (MLFS). TComplete remission, based on the 2017 European Leukemia Net guideline, is achieved if bone marrow blast is $<5 \%$ with there is no circulating blast and blast with Auer rods, no extramural appearance, absolute neutrophil count of $\geq 1.0 \times 10^{9} / \mathrm{mm}^{3}$, and platelet count of $\geq 100 \times 10^{9} / \mathrm{mm}^{3}$. 9 In addition to hematological examination of peripheral blood smear and bone marrow smear, Minimal Residual Disease (MRD) assessment can be applied to assess the therapeutic response and prognosis in AML patients. CR without minimal residual disease (CRMRD) is known as complete remission and is established when no genetic markers are obtained in real-time quantitative polymerase chain reaction (RT-qPCR) or when no genetic blast markers are identified by multi-color flow cytometry examination. ${ }^{10,11}$ In the SWOG S0106 study, Othus et al. have reported a Multiparameter Flow Cytometry (MPFC) test when complete remission is achieved as a stronger predictive factor for relapse-free survival (RFS) when compared to age, cytogenetic before treatment, or mutation of NPM1 and FLT3.10,11,12 This patient underwent induction and consolidation chemotherapy and one month after consolidation chemotherapy the patient was found to meet complete remission criteria, i.e. no circulating blasts and blasts with Auer Rods in peripheral blood, absolute neutrophil count of 2520 $\left(>1.0 \times 10^{9} / \mathrm{mm}^{3}\right)$, platelet count of $350 \times 10^{9} /$ $\mathrm{mm}^{3}\left(>100 \times 10^{9} / \mathrm{mm}^{3}\right)$ and no extramedular appearance; however, bone marrow aspiration was not performed in this patient that no data were available on the number of blasts in the bone marrow.

In AML patients, cytogenetic abnormalities are the most dominant independent prognostic factors in assessing prognostic factors for complete remission, $\mathrm{t}$ recurrence risk, and OS based on multivariate analysis other than age, type of AML (de novo or secondary), and white blood cell count. ${ }^{13}$

Factors that influence the good prognosis of this patient are young age, white blood cell count when diagnosed of $<100 \times 10^{9} / \mathrm{mm}^{3}$, absence of blood abnormalities that precede leukemia, absence of previous therapy for other cancers, absence of therapy that infiltrated the central nervous system (chemotherapy drugs are difficult to reach the central nervous system area), and response to induction therapy (if the patient responds well by achieving rapid complete remission, the prognosis will be better).

During the 5-year period at RSHS, Bandung, only 12 AML patients underwent chemotherapy. This low number is largely due to problems related to side effects management that should be provided during chemotherapy, namely severe neutropenia, anemia, and thrombocytopenia. of the 12 patients only 1 person managed to survive and achieved a complete response to induction and advanced chemotherapy with cytarabine and daunorubicin without undergoing HSCT.

Therapy given to AML patients includes induction chemotherapy, consolidation, and bone marrow transplantation with the aim of achieving longest complete remission period possible without recurrence. The commonly seen side effects of chemotherapy are severe neutropenia to febrile neutropenia and thus requires additional therapies during chemotherapy. Most AML patients in Dr. Hasan Sadikin General Hospital do not undergo chemotherapy or bone marrow transplant due to financial reasons. This study has presented an example of AML patient who can achieve a complete response to chemotherapy without bone marrow transplant because of the provison of maximum supportive therapy.

\section{References}

1. Barnett A, Wetzler M, Lowenberg B. Therapeutic advances in acute myeloid leukemia. J Clin Oncol. 2011;29:487-94.

2. Storey S, Fowler T, Bryant AL. Comorbidity, physical function and quality of life in older adults with AML. Curr Geriatr Rep. 2017; 6(4):247-54.

3. Larson R, Lowenberg B, Rosmarin AG. Induction therapy for acute myeloid leukemia in younger adults. 2019. [cited February 2019]. Available from: http:// www.uptodate.com.

4. Dombret H, Gardin C. An update of current treatments for adult acute myeoid leukemia. Blood. 2017;127(1):53-61.

5. Chen X, Xie H, Wood BL, Walter RB, Pagel 
JM, Becker PS, et al. Relation of clinical response and minimal residual disease and their prognostic impact on outcome in acute myeloblastic leukemia. J Clin Oncol. 2015;33(11):1258-64.

6. Muller LP, Tidow CM. The indications for allogeneic stem cell transplantation in myeloid malignancies. Dtsch Arztabl Int. 2015;112(15):262-70.

7. Thol F, Schlenk RF, Heuser M, Ganser A. How I treat refractory and early relapsed acute myeloid leukemia. Blood. 2015;126(3):31924.

8. NCCN. Clinical Practice guidelines in oncology (NCCN Guidelines) acute myeloid leukemia version 2. Plymouth Meeting, Pennsylvania: NCCN; 2018.

9. Döhner H, Estey E, Grimwade D, Amadori S, Appelbaum FR, Büchner T, et al. Diagnosis and management of AML in adults: 2017
ELN recommendations from an international expert panel. Blood. 2017;129(4):424-47.

10. Estey E, Othus M, Lee SJ, Appelbaum FR, Gale RP. New drug approvals in acute myeloid leukemia: what's the best point?. Leukemia. 30(3):521-25.

11. Othus M, Wood B, Estey E, Petersdorf S, Appelbaum F, Erba H, et al. Effect of minimal residual disease (MRD) information on prediction of relapse and survival in adult acute myeloid leukemia (SWOG S0106). Leukemia 2016;30(10):2080-3.

12. Ommen HB. Monitoring minimal residual diseases in acute myeloid leukaemia: a review of the current evolving strategies. Ther Adv Hematol. 2016;7(1):3-16.

13. Grimwade D, Hills RK. Independent prognostic factors for AML outcome. Hematology Am Soc Hematol Educ Program. 2009:385-95. 